\title{
INTERACTIVITY AND IDENTIFICATION INFLUENCES ON VIRTUAL SHOPPING
}

\author{
Echo Huang \\ National Kaohsiung First University of Science and Technology \\ No.1, University Rd., Yanchao Dist., Kaohsiung City 824, Taiwan \\ echoh@nkfust.edu.tw \\ Yu-Ting Huang \\ National Kaohsiung First University of Science and Technology \\ No.1, University Rd., Yanchao Dist., Kaohsiung City 824, Taiwan \\ yt.huang705@gmail.com
}

\begin{abstract}
The rapid development of virtual shopping through social networking sites raises important research questions. Social networking site features can shape members' behavioral intentions toward virtual shopping. In this study, the S-O-R model is used to examine the effects of online stimuli on members' emotional states and responses. The structural equation model (SEM) tests the conceptual model and hypotheses. The findings show that both interactivity and identification factors shape members' trust, flow and purchase intention.
\end{abstract}

Keywords: S-O-R, Trust, Flow, Interactivity, Identification, Virtual Shopping, Social Network Sites

\section{INTRODUCTION}

With the growing population of social networking sites (SNSs), many online game providers have started to work with social networking sites for potential business opportunities. According to Plus Eight Star, Asians spend $\$ 5$ billion a year on buying virtual goods (VGs) through social networking sites, accounting for $80 \%$ of the international market. Despite the economic downturn, for the VG market will likely exceed $\$ 100$ billion globally in this decade. 
The rapid development of virtual shopping in SNSs raises important research questions. How do providers influence users' VG awareness? What features influence users' emotional states? To answer these questions, this study employs the S-O-R model ${ }^{1}$ to examine the effects of platform-based stimuli on users' psychological states and their behavioral intentions toward virtual shopping.

\section{STIMULUS-ORGANISM-RESPONSE (S-O-R) MODEL}

The stimuli-organism-response ${ }^{1} \quad(\mathrm{~S}-\mathrm{O}-\mathrm{R})$ model states that psychological responses to the environment mediate the relationship between the environment and an individual's behavior. The S-O-R model posits that environmental cues act as stimuli that affect consumers' psychological states (organism), which in turn affect their behaviors (responses) $^{2}$.

In online shopping literature, most studies indicate that websites with a high level of interactivity lead to cognitive and affective motivational states as well as purchase intentions ${ }^{2,3}$. Previous studies had examined website features that influence consumers' psychological processes and lead to their usage $^{4,5}$ or purchase behaviors $2,3,6$. Previous studies of online shopping have focused on physical products only little mentioned of virtual products in the context of SNSs. To address this gap, the S-O-R model is used to explain the effects of platform-based features on virtual shopping in SNSs.

\section{THE RESEARCH MODEL AND HYPOTHESES}

Based on the theoretical background presented above, a research model is developed. The dependent variables are individuals' behavioral intentions toward virtual shopping in a SNS. Trust is a rational state, while flow is an emotional state; both have positive impacts on purchase behavior ${ }^{7,8}$. Thus, the intermediary variables are trust and flow. Interactivity and identification are used as the independent variables in the study ${ }^{9}$ they influence both rational and emotional factors ${ }^{10,11}$.

The literature indicates that trust has long been regarded as a catalyst in consumer-merchant relationship, because it provides expectation of successful transactions ${ }^{12,13}$. Trust is a dynamic rational process that influences customer satisfaction toward products and merchants ${ }^{7}$. It has always been an important element in influencing consumer behavior and has been shown to highly significant influence in uncertain environments ${ }^{14}$. A high degree of trust in the social networking site will show higher intentions to purchases and repeated purchases ${ }^{14,15}$ as well as higher use intention ${ }^{16}$. 
Flow of SNSs refers to the degree of pleasure and time spent of a user on a social networking site ${ }^{17,18}$. Previous studies of online communities had proposed the positive influence of flow on member use intention ${ }^{19}$ and purchase behaviors ${ }^{7,20,21}$. These lead to the following hypotheses:

H1: Trust has a positive influence on intention to use virtual goods.

H2: Trust has a positive influence on intention to buy virtual goods.

H3: Flow has a positive influence on intention to use virtual goods.

H4: Flow has a positive influence on intention to buy virtual goods.

Interactivity refers to a user's perceived responsiveness, perceived control, and perceived connection to a web-based platform ${ }^{22,23}$. Previous literature indicates that interactivity has a significant effect on trust ${ }^{10}$ and flow ${ }^{11}$. In addition, many studies have demonstrated that a higher degree of interactivity could bring online users more experience of flow ${ }^{11,24}$.

Identification refers to a user's self-esteem and commitment to group $^{25,26}$. Social identity theory ${ }^{27}$ posits that trust can be used to measure tangible and intangible benefits gained from communities and members. Identification helps users to communicate and interact with like-minded online friends. A high degree of social identity can bring strong satisfaction for users, increasing the level of time invested on the site ${ }^{28}$. Previous studies have shown that social identity positive affects trust ${ }^{27}$ and flow ${ }^{28}$. Hence, the following hypotheses are proposed:

H5: SNS interactivity has a positive influence on trust of a SNS.

H6: SNS interactivity has a positive influence on flow of a SNS.

H7: SNS identification has a positive influence on trust of a SNS.

H8: SNS identification has a positive influence on flow of a SNS.

\section{DATA ANALYSIS AND RESULTS}

\subsection{Sample and Data Collection}

This study conducted a web-based survey to obtain data to test the research hypotheses. A banner with a hyperlink connecting to our website was posted on Facebook in 2010. A total of 215 valid samples are replied over a four-week period. The samples are composed of $48 \%$ female and $52 \%$ male. Of $54 \%$ age ranged from 26 to $35,30 \%$ were $18-25 ; 15 \%$ were $36-45$, and only $1 \%$ were over 46 . Most of respondents had received a college degree (73\%); $20 \%$ had master degree; and 7\% graduated from high 
school. Of 33\% reported that they gained monthly between $\$ 600$ and $\$ 1000$, $27 \%$ less than $\$ 600,27 \%$ between $\$ 1,000$ to $\$ 2,000$, and $13 \%$ over $\$ 2,000$.

\subsection{Measurement}

A questionnaire was developed based on previous literature. Interactivity is defined as the degree of an individual's perceived responsiveness, perceived control, and perceived connection to a social networking site ${ }^{11,22,23}$. Identification refers to the degree of an individual's self-esteem and commitment to groups in a social networking site ${ }^{25,26}$. Trust is defined as the degree of an individual's confidence in a social networking site $^{8,12}$. Flow refers to the degree of pleasure and focus of a user using virtual goods in a social networking site ${ }^{17,18}$. Behavioral intention is defined as the likelihood that an individual intention towards virtual goods in the near future ${ }^{29}$. Each item was rated on a scale of 1 to 5 , where 1 is "disagree" and 5 is "agree".

Table 1. Correlation matrix and discriminant validity

\begin{tabular}{ccccccccc}
\hline & CR & AVE & INT & SI & Trust & Flow & IU & IB \\
\hline INT & .922 & .747 & $\mathbf{. 8 6 4}$ & & & & & \\
SI & .937 & .747 & .586 & $\mathbf{. 8 6 4}$ & & & & \\
Trust & .916 & .732 & .708 & .695 & $\mathbf{. 8 5 6}$ & & & \\
Flow & .923 & .750 & .593 & .714 & .645 & $\mathbf{. 8 6 6}$ & & \\
IU & .890 & .730 & .316 & .464 & .365 & .465 & $\mathbf{. 8 5 4}$ & \\
IB & .950 & .850 & .559 & .597 & .548 & .618 & .354 & $\mathbf{. 9 2 1}$ \\
\hline
\end{tabular}

Note: INT: interactivity; SI: social identification; IU: Intention to use; IB: Intention to buy

\subsection{Statistical Analysis and Results}

A structural equation mode with AMOS 18 was used to assess the measurement and structural model. The seven fit indices indicated that the research model had met the criteria for a model fit. Confirmatory factor analysis (CFA) was employed to evaluate the convergent validity for modeled constructs and discriminant validity. Convergent validity was evaluated for the measurement scales using two criteria suggested by Fornell and Larcker ${ }^{30}$. Composite reliability (CR) should exceed $0.70^{31}$. As shown in Table 1, all of the conditions for validity were met. 
$\mathrm{S}$

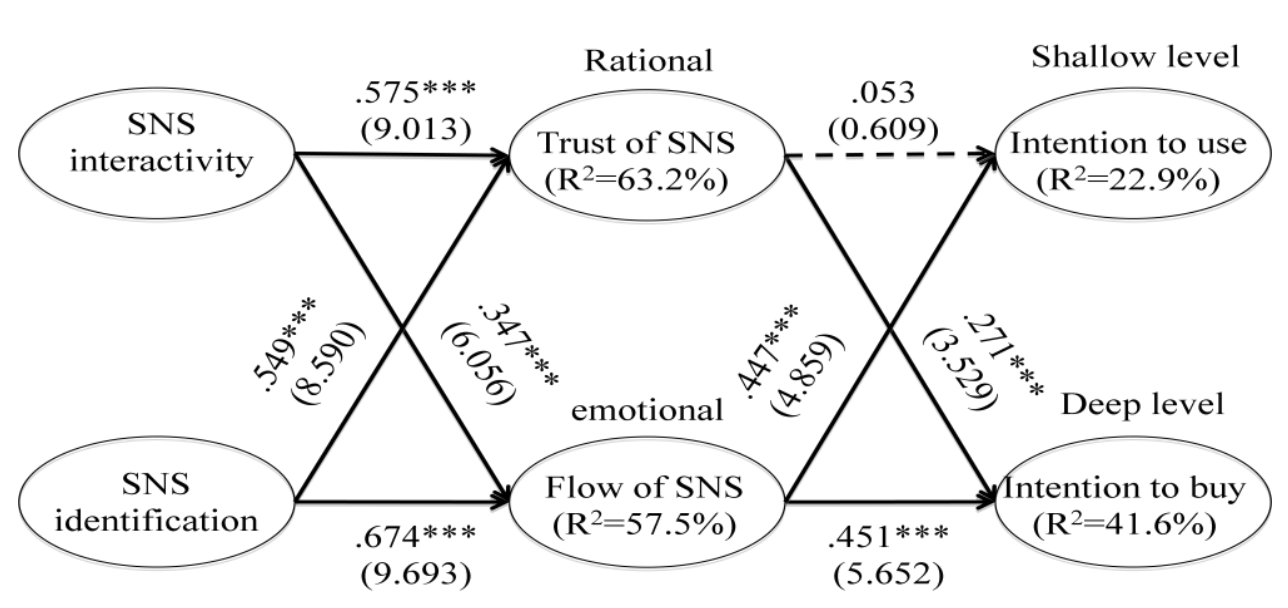

Note $: \chi 2 / \mathrm{df}=1.752, \mathrm{GFI}=0.89, \mathrm{AGFI}=0.85, \mathrm{NFI}=0.93, \mathrm{IFI}=0.97, \mathrm{CFI}=0.97, \mathrm{RMSEA}=$ $0.059 ; * p<0.05, * * p<0.01, * * * p<0.001$

Figure 1. Path coefficient analysis

Only one of eight hypotheses is non-significant as shown in Figure 1. The positive relationships among purchase intention, trust, flow of SNS, SNS interactivity and SNS identification were supported. Interactivity had significant influences on trust and flow; thus, H5 and H6 were supported. Identification had significant influences on trust and flow; thus, $\mathrm{H} 7$ and $\mathrm{H} 8$ were supported. Interactivity and identification explained $63.2 \%$ of the variance in trust and $57.5 \%$ in flow. In addition, trust had a significant influence on purchase intention; thus, $\mathrm{H} 2$ was supported. However, the coefficient between trust and use intention was 0.053 ; therefore, H1 was rejected. Flow had a significant influence on use and purchase intentions; thus, $\mathrm{H} 3$ and $\mathrm{H} 4$ were supported. Trust and flow explained $22.9 \%$ of the variance in use intention and $41.6 \%$ in purchase intention.

\section{DISCUSSION AND CONCLUSION}

The aim of this study was to examine the effects of online stimuli on member's motivational states and their behavioral intentions toward virtual shopping in a social networking site. Based on the theoretical paradigms of $\mathrm{S}-\mathrm{O}-\mathrm{R}$, we confirmed that consumers' emotional and rational state were somehow changed when consumers were exposed to different level of platform-based stimuli (interactivity and identification). Based on our findings, providing a controllable, responsive, connected mode of interactivity is important to increase users' motivations. Consequently, SNS 
operators should advance identification features, combining of self-categorization, self-esteem, and commitment, which significantly shape users' motivations as well.

Both of motivational states generated behavioral intentions toward buying of virtual goods in a SNS. However, the relationship between trust and intention to use is not supported. A possible reason is that a user's trust in a platform does not automatically transfer to trust in virtual goods. An individual may be happy to use and buy the site's self-developed VGs but may be not glad to use other developers' VGs. Obviously, the difference between trust-to-platform and trust-to-VG should be further examined to advance the understanding of virtual shopping in an online platform.

\section{REFERENCES}

[1] A. Mehrabian, and J.A. Russell, An approach to environmental psychology. Cambridge, MA: MIT Press, 1974.

[2] Z. Jiang, J. Chan, B.C. Tan, and W.S. Chua, Effects of interactivity on website involvement and purchase intention. Journal of the Association for Information Systems, 11(3), p34-59, 2010.

[3] D.V. Parboteeah, J.S. Valacich, and J.D. Wells, The influence of website characteristics on a consumer's urge to buy impulsively. Information Systems Research, 20(1), p60-78, 2009. http://dx.doi.org/10.1287/isre.1070.0157.

[4] K.P. Pauki, R.L. Gilson, and D.R. May, Anxiety and avoidance: The mediating effects of computer self-efficacy on computer anxiety and intention to use computers. Review of Business Information Systems, 11(1), p57-64, 2007.

[5] P. Song, H. Xu, A. Techatassanasoontorn, and C. Zhang, The influence of product integration on online advertising effectiveness. Electronic Commerce Research and Applications, 10(3), p288-303, 2011. http://dx.doi.org/10.1016/j.elerap.2010.09.003.

[6] H.H. Chang, and S.W. Chen, The impact of online store environment cues on purchase intention: Trust and perceived risk as a mediator. Online Information Review, 32(6), p818-841, 2008. http://dx.doi.org/10.1108/14684520810923953.

[7] J. Koh, and Y.G. Kim, Sense of virtual community: A conceptual framework and empirical validation. International Journal of Electronic Commerce, 8(2), p75-93, 2004.

[8] R. Morgan, and S.D. Hunt, The commitment-trust theory of relationship marketing. Journal of Marketing, 58(3), p20-38, 1994. http://dx.doi.org/10.2307/1252308. 
[9] R.W. Belk, Situational Variables and Consumer Behavior. Journal of Consumer Research, 2(3), p157-164, 1975. http://dx.doi.org/10.1086/208627.

[10] D.H. McKnight, and N.L. Chervany, What trust means in e-commerce customer relationship: An interdisciplinary conceptual typology. International Journal of Electronic Commerce, 6(2), p35-59, 2002.

[11] M. Koufaris, A. Kambil, and P.A. Labarbera, Consumer behavior in web-based commerce: An empirical study. International Journal of Electronic Commerce, 6(2), p115-138, 2002.

[12] L.V. Casaló, C. Flavián, and M. Guinalíu, The influence of satisfaction, perceived reputation and trust on a consumer's commitment to a website. Journal of Marketing Communications, 13(1), p1-17, 2007. http://dx.doi.org/10.1080/13527260600951633.

[13] P.H. Schurr, and J.L. Ozanne, Influences on exchange processes: Buyers' preconceptions of a seller's trustworthinese and bargaining toughness. Journal of Consumer Research, 11(4), p939-953, 1985. http://dx.doi.org/10.1086/209028.

[14] S.L. Jarvenpaa, and N. Tractinsky, Consumer trust in an Internet store: A cross-cultural validation. Journal of Computer Mediated Communication, 5(2), p1-35, 1999. http://dx.doi.org/10.1111/j.1083-6101.1999.tb00337.x.

[15] D. Gefen, E-commerce: The role of familiarity and trust. Omega, 28(6), p725-737, 2000 . http://dx.doi.org/10.1016/S0305-0483(00)00021-9.

[16] J.E. Swan, M.R. Bowers, and L.D. Richardson, Customer trust in the salesperson: an integrative review and meta-analysis of the empirical literature. Journal of Business Research, 44(2), p93-107, 1999. http://dx.doi.org/10.1016/S0148-2963(97)00244-0.

[17] J. Lu, C. Liu, C.S. Yu, and K. Wang, Determinants of accepting wireless mobile data services in china. Information \& Management, 45(1), p52-64, 2008. http://dx.doi.org/10.1016/j.im.2007.11.002.

[18] J. Moon, and Y. Kim, Extending the TAM for world-wide-web context. Information \& Management, 38(4), p217-230, 2001. http://dx.doi.org/10.1016/S0378-7206(00)00061-6.

[19] J. Manuel, and S. Franco, WebCT- The quasimoderating effect of perceived affective quality on an extending Technology Acceptance Model. Computers \& Education, 54(1), p37-46, 2010.

[20] C.L. Hsu, and H.P. Lu, Why do people play on-line games? An extended TAM with social influences and flow experience .Information\& Management, 41(7), p853-868, 2004. http://dx.doi.org/10.1016/j.im.2003.08.014.

[21] D.M. Szymanski, and R.T. Hise, E-Satisfaction: An Initial Examination. Journal of Marketing, 76(3), p309-322, 2000. 
http://dx.doi.org/10.1016/S0022-4359(00)00035-X.

[22] G.J. Johnson, G.C. Bruner II, and A. Kumar, Interactivity and its facets revisited: Theory and empirical test. Journal of Advertising, 35(4), p35-52, 2006. http://dx.doi.org/10.2753/JOA0091-3367350403.

[23] T.M. Lee, The impact of perceptions of interactivity on customer trust and transaction intentions in mobile commerce. Journal of Electronic Commerce Research, 6(3), p165-180, 2005.

[24] D.L. Hoffman, and T.P. Novak, Marketing in hypermedia computer-mediated environments: Conceptual foundations. Journal of Marketing, 60(3), p50-68, 1996. http://dx.doi.org/10.2307/1251841.

[25] O. Kwon, and Y. Wen, An empirical study of the factors affecting social network service use. Computers in Human Behavior, 26(2), p254-263, 2010. http://dx.doi.org/10.1016/j.chb.2009.04.011.

[26] U.M. Dholakia, R.P. Bagozzi, and L.K. Pearo, A social influence model of consumer participation in network- and small-group based virtual communities. International Journal of Research in Marketing, 21(3), p241-263, 2004. http://dx.doi.org/10.1016/j.ijresmar.2003.12.004.

[27] T.R. Tyler, Trust and democratic governance. In V. Braithwaite, and M. Levi (Eds.), Trust and Governance (p269-294). New York: Russell Sage Foundation, 1998.

[28] L. Leung, Impacts of Net-generation attributes, seductive properties of the Internet, and gratifications-obtained on Internet use. Telematics \& Informatics, $\quad 20(2), \quad$ p107-129, 2003. http://dx.doi.org/10.1016/S0736-5853(02)00019-9.

[29] P.A. Pavlou, and D. Gefen, Building effective online market places with institution-based trust. Information Systems Research, 15(1), p37-59, 2004.

[30] C. Fornell, and D. Larcker, Structural equation models with unobservable variables and measurement error: Algebra and statistics. Journal of Marketing Research, 18(3), p328-388, 1981. http://dx.doi.org/10.2307/3150980.

[31] R.P. Bagozzi, and Y. Yi, On the evaluation for structural equation models. Journal of the Academy of Marketing Science, 16(1), p74-94, 1988. http://dx.doi.org/10.1007/BF02723327. 